\title{
On Love and Work: A Vow of Wholeness in Writing
}

\author{
ANNE C. KLEIN
}

Noting that academic writing typically falls in the category of work, this piece considers the relationship such writing might have with love. Animated by its observation that love's affinity with wholeness distinguishes it from work's tendency to divide a subject from herself, the essay playfully develops this contrast by telling a story of writing and wholeness. This story attempts to embody the contrasts of which it speaks, and in the process, to discover a counterpoint to the work of writing.

Any work that cuts you in two, leaves part of you out, cannot be something you love. Love of all kinds, romantic, spiritual, and everything in between, yearns for and yields union. Work without love thrives on distance. Work involving language is doubly cursed, for in the very arc of their effectiveness, words divide. They disrupt silence and unconsciousness, partly because they carry enough conceptual burrs on them to hollow out a place of their own. This keeps them distinct from other words, images, and associations, working through entwined yet isolated jots of meaning. The words of work are too deeply associated with doing, with the labor of self-configuration, to welcome oceans of sheer being. Words are born of difference and contradiction; and work, even when not explicitly involved in producing or responding to language, thrives on difference as well. We work on things, meaning we are separate from them, we work for someone, meaning we do not fully own our purpose or activity, we work under someone, meaning we surrender authority, we work to get something or somewhere, meaning neither our work nor our being is satisfactory in and of itself. Why then would we love it? Or the self who dismisses part of her being to accomplish it?

Is it possible to work, to think, to write, to perform, and still love? After all, we do not love on, for, under or to get. (Or do we do all these things and wonder 
if it is "really" love?) If work is about doing and trying, love is about being and flowing. If you are paid for it, can you simply love it? If you love it, is it work? If it's work, can you love both it and yourself doing it? Does one have to be sacrificed to the other? Can these two fundamentally different approaches to the world be reconciled under even the most optimal circumstances? How can we begin to imagine this?

These paragraphs, though born of inspiration, were work. They had to slog through mud to get here, fight to take shape, and also escape the solidifying structures of my effortful mind. Yet I also know that words just breeze along sometimes, humming as they go. Though I work hard at writing, my body still somewhere knows what humming feels like. So I know this:

Words aren't just tools

For getting things straight

pinning them down,

holding them up

Don't use them like hammers, knives.

Or even as thumbtacks.

Don't merely handle them.

Hold them, melt them to your marrow

From where,

Nourishing your heart,

Loving your soul,

They rise again, aloft from your lungs

Flowing out graciously

Helping the world exist.

So let me say something about my experience with the work of words, and the love of them. This is also the story of how I came to understand the relationship between work and love as isomorphic to the forces that rend from each other doing and being, speech and silence, constricted form and spacious emptiness.

Long before I could read or write, I was fascinated with typing: the clicking keys, and in those days, the smacking sound of key against paper. Words created with such potent sound and swift motion, I surmised, must have compelling power. They are not simply expelled from a body into bodilessness; no, whatever absences they entail, they also carry force and connection.

This I felt deeply as a child, and I have since learned it to be the way of many ancient traditions. Written or oral, such words are not just aggregated symbols or slices of meaning. In traditions of Tibetan Buddhism, for example, words of teaching are part of another ecology. Never reduced to mere data, they are 
valued, nourished, and dispensed with the care you take when you know you are dealing with something potent, precious, and alive. Such words cannot be spoken as work, yet are best heard with effortless and receptive joy. Hearing such special words in this way can expand spaciousness and awareness in every part of your life. Such are the heightened words of dharma, of teaching. They are the heart-words of a teacher to a student, sounds that melt directly into transformative experience for the listener. This happens as much because of the hearer's openness as because of the words' own weight. Such words are alive, their power by no means dependent on their meaning alone. Being alive, their energy is nurtured; these words are not to be overused, sold, published or taken advantage of in any way. They are dispensed only under proper circumstances and to appropriate persons. The less frequently spoken, the greater their power, and the more deeply they are received, for they are recognized above all as messages of love, whatever else they may say and convey.

From this perspective, the work of scholarly writing is constrained to mere meaning. One left-brain side addressing another, leaving much of the body out in the process. This is clearly work, and the hardest part may not be writing out the brain's insight, but dismissing the other body parts that also wish to speak. When they are allowed to speak, they tend toward the surging of poetry, the singing of songs. There too meaning becomes secondary to other qualities, and a quality of play leaps in. Is play intrinsically easier to love than work? Is this because it is easier to be whole in playfulness than in workfulness? Is there something about certain kinds of effort that cuts us off from ourselves-especially from the soft underbelly of feeling, of safe womb enclosure where all is rounded wholeness, free of the sharp edges of incisive articulation that cuts the perceived world, and our perception, into pieces?

My initial fascination with words and my concurrent blind faith in their physical power knew nothing of pieces. I was ready to put my whole heart into writing, the way you can only do before your fulsome sense of expressiveness is broken down into letters by the ability to read and write.

When I was four my parents acquired a black Royal typewriter, with round, shiny keys edged in chrome. My parents did not really type much, but they spoke exuberantly: German, Slovak, and French flowed unencumbered, and most especially their native Hungarian, along with their more recently acquired and surprisingly adroit English-all rolled off their tongues with equal ease. My own words, however, were limited to English, the only language in which my parents communicated with me. Although I could neither speak nor understand it, Hungarian filled my ears day in and day out, whenever they conversed with each other. Hungarian was the sound of home, but not a home I could speak in. To this day it is familiar as a mother tongue and altogether foreign.

The frustration of daily, hourly, being exposed to two and many languages with access only to one and no way of translating from it to the other exploded 
in me as mad energy for writing. I had the opposite of writer's block, driven to tell what I could not say. Since I could not yet form letters, much less spell words, this was frustrating. Still, I was determined to fashion my one language into as many forms as possible.

Consequently, the new and shining typewriter pulled me like a magnet. But I was not allowed near it until one winter holiday when I was confined to my room to recover from a fever. How was I to amuse myself? My parents' solicitous attitude made me bold: "I want the typewriter," I said.

It was brought in and placed on the desk by my father. My mother pulled out some paper from an old notebook. I left my bed and sat on the chair in my pajamas, with the old-style radiator sending out healing heat under the desk. I began to type. Short words, long words, mere strings of letters really, and thumbing the space bar with assurance whenever the spirit moved me, blissfully free of the need (since so familiar) to constrain myself to the vocabularies of any known tongue.

This was not work. Was it writing? This happy excitation rushing through my body, pouring out as latticed words? Mere letters and syllables really, expressing only the inchoate exuberance that prompted them. It was the very opposite of writer's block. No need to search for words, a secret möbius movement brought them to me. They rushed in so fast and raucously I hardly knew them, jumbling together in indecipherable clumps. I didn't care; I was writing wholeness. These words weren't objects to be manipulated, they were friends at my party-the louder, the more sheer drumming exuberance the better. Meaning was in the impulse. Their hum was all.

Needless to say, since gaining literacy I have never again composed with the sheer physical aplomb and full-bodied confidence of that initiatory authoring. And yet the love for the work of writing is still in me, as is the desire to find a way back to the kind of body that can love and write at the same time. A body that words would willingly, maybe even playfully, enter. "The art of the writer consists in little by little making words interest themselves in his books" says Jabès (in Derrida 1978, 65).

What would such a body write? Footnotes? Fiction only? Ward Just, I am told, has said that writing novels is not hard work. (My scholarly writing is.) And that novels are about translating wanting and desire into prose. The feel of desire coursing through the body, pouring out luscious words. I can relate to that. What does my scholarship translate into prose? What are the energetics of such translation?

If effort is contraction and love expansion, this explains a great deal. Asian Buddhist traditions such as Ch'an and Dzogchen, which charm adherents with magnificent descriptions of a perfection already complete at the heart of their being, find effort an unnecessary wrinkle in the fabric of what is. An ancient poem from perhaps the earliest strata of Tibetan writing, the Excellent Collection of Essential Precepts, expresses it thus: 
... In uncontrived mindnature.

No effort, no thought, limpid.

No reflection, no analysis,

Naturally placed there. (Cited in Li-shu sTag-ring 1972, 53.1)

The eighth-century Dzogchen meditation master and scholar Lishu Daring, who cites the above excerpt in his scholarly opus, The Authenticity of Open Awareness (traditionally dated from the eighth century, but probably at least two centuries later) immediately segues from it to another ancient verse from the no longer extant Heart of Essential Precepts:

\section{When shown this errorless essential precept \\ One's own mind is effortlessly known, \\ Hope and doubt gone, fruition comes on. (in Li-shu sTag-ring $1972,53.2)^{1}$}

The "errorless essential precept" has another beautiful name; elsewhere in his and other writings it is called unbounded wholeness, is a ripening metaphor for the reader, the focus of much work for the writer (in particular, this writer in the midst of a book on the topic) — an experienced reality of bliss and love, we are told, for the practitioner who steeps her being in contemplation of it. Hope and doubt obscure wholeness through their work of dividing us from the hoped for, and fencing off the feared, about which we have grave doubt.

Therefore, anticipating wholeness, practitioners give up hope for happiness, giving their happiness away to all in need; give up fear of sorrow, taking on all the world's pain to free the world of it. (Shantideva 1996, 96) ${ }^{2}$. This is the mind that opens to unbounded wholeness. Such wholeness, contra Derrida, can never be shaken, nothing ever falls out of it. More than this, shaking cannot rupture it or even reveal anything outside it. For one who has truly given up hope and fear, honing a heart-essence common to both, shaking and all other activities are the dynamic display of this wholeness. As is effort. As is work. Love, too, is part of its display, though not in a way that challenges wholeness. Still, neither work nor effort can rupture it; ultimately they, like love, can only celebrate it. For in this vision of completeness, proof of unbounded wholeness lies exactly with the existence of its multiciplicities, its contradictions, which therefore do not fundamentally oppose each other. This is very different from the mobile totalities of Derridan différance, a form of play that is at once colluding and disruptive of multiple wholenesses which are constantly shaking down (ciere) their shape, contents, everything. This is, after all, what Derrida apparently means by his word sollicitare: the shaking down (ciere) of everything (sollus).(Bass, 1978, $\mathrm{xvi}$ ) Can this shaking everything compare to wholeness?

The wholeness of esoteric Buddhism ${ }^{3}$ is the fullsome and joyous, endlessly combustible and beginningless play of subject and object dissolved together. It is recognizable only in the face of love, not work. Its language is always poetic, 
froth on the ocean, giving even the casual passerby an inkling of the depths that froth, like words, will merely decorate, not describe, undermine, or reveal. ${ }^{4}$

Or so the old traditions claim. Yet if we return to what we know about writing, if we consider with Jean Cohen, that the "principle of contradiction" is the "fundamental principle of logic and the norm that governs language ..." (Johnson 1987, 120) how could we take wholeness seriously? But writing wriggles around and slips through the logic of contradiction in its very artfulness. The play of words, born of a love of word power, has a potency that goes beyond mere meaning. It lies coiled in catchy rhythms that mimic the body's own rhythms (think Edgar Allan Poe), or stirs up streams of connection with ancient sources that bring the sacred into presence.

There is importance, honor, connection, rigor, and accomplishment in work. But very little magic. Love may have all or none of the above, but is always magical. Then what of the love and work in writing?

Surely these can be joined together. Partly because their different energies, the true source and outcome of words, can simultaneously-or nearly-flow through and occupy the body. Even if one sometimes thwarts the others, they are both there, interacting, bringing dynamism to what would otherwise (but could never) be a merely inert interiority.

More and more, I see wholeness as inevitable, even when unrecognized. Wholeness is uncontrolled and uncontrollable, not to be confused with totalities that merely hide what they are excluding. Wholeness is not the province of prose alone, nor of logic. It encompasses more, without denying these either. A fluid möbius movement allows the deep conversion from work to love. Believing this, I would take a vow of wholeness before my computer, swearing never to set aside any part of my being as I write. Would any words at all issue from a body, from a being that is whole? Imagine a fulsome movement from all the cells, an outpouring of whole body and being. Such writing could, like sacred words - and the sacred is always whole as well as holy-pour through others' cells and being and incorporate them, so that the lonely writer is not the sole subject of her writing.

How can this be, you say? I only just came to believe in the possibility myself. Listen to my story.

The hum of my childhood never faded completely. But once I mastered the alphabet and reading, words clogged the möbius movement, they stopped swirling and humming together. Noticing this, I outgrew my childish sense that they could all join in for one open raucous festival. But my passion to test the power of typing remained, reinvigorated, in fact, as I hobnobbed with romance and other languages. When I finally burst through the English barrier of my childhood, parlez vous, parlez vous, I was thrilled. Finally, I could translate across systems, first systems of language, and then other systems as well. How I wanted to make the most of this! 
As I said, I early loved typing. I came to excel in it. I loved learning its patterns: the letters of the left hand, abcdefg, and of the right, hijklmnop. Then back to the left hand in the upper row, qrst, and a quick pass to the right for $u$, a flash to the left with $v w x$, the quick pass again toy, and then finish at $z$. The pattern amuses the mind, the speed charges my body. Perhaps it was partly this charge that attracted the first love of my life, someone who on every level spoke my language. Charged with joy, in class I typed my teacher's words on the desk top to see if my fingers could keep pace with them; after a sentence or two I was always behind. Even so, in ninth grade there was a typing contest, which I proudly won, hands down.

In college I earned spending money typing other people's English 101 papers and a dissertation on Wittgenstein. This was definitely work, formed from the play of fingers I continued to love. I completed my own dissertation, on the relationship of hard intellectual work to mystical experience, in a burst of passion and sweat, composing, polishing, and retyping the final chapter in a single day. By that time I had the kind of electric typewriter that could erase letters and lines at the touch of a button. The true instrument of my need was yet to come.

But even before computers, graduate school had been a time of serious typing for me, and an expansion of my linguistic horizons as well. My long-lost first love phoned to say that Tibetans had the last word on language magic. I enrolled in Tibetan class and quickly discovered that learning Tibetan was not like learning French-there were no textbooks for it. Eminent red-robed Lamas came from their exiled homes in India and Nepal to help us out. We looked at texts and, above all, we tape-recorded every word they said in explanation of those texts. "This is form," a recent arrival from Dharamsala told us, pointing to my taperecorder. "And here is emptiness," he added, still pointing to the same place.

In order to learn a language, you must hear it. In order to hear Tibetan often and slowly enough to speak it, we used tapes. On these tapes the teachers from Tibet, the Lamas, discussed many things, like the mysterious relationships between sound and meaning, intention and action. Some of the greatest Tibetan scholars of their generation poured the sound of their words into our ears and onto our tapes. But mere sound is insufficient for graduate students smitten with letters. After hearing the Lamas' lectures, everyone wanted to study them in print. It thus became necessary to turn that sound into writing. That meant serious typing. It meant me.

During those years I typed out the sounds of four different books. The books were my professor's, the products of hard work. But in typing them from tape, their original style of expression, I developed a new art form. I became expert in transforming sound into typing, and especially unedited speech into edited writing with a seamless flow of flashing finger action. It was my joy to dispel the subtle boundary between sound and letters as quickly as possible, to unite formless sound and letter formation in this very modern manner. 
Of course, the sound and form of letters are inextricably mixed for any literate person. Typing directly from speech articulated for me the profound conjunction of these two, their functions now separated by only the briefest of synapses. It was my joy to leap across and thus dispel that boundary as quickly as possible, to unite formless sound and letter formation in this very modern manner; to cross with increasing ease again and again between gestational silence, where everything exists in potential, and the narrow forms of speech emerging from it, and in the process, to realize that the limits of each arena, like the boundary between them, is illusory. That this illusion flourishes when the profound fullness of open, some say empty, inner spaciousness is ignored. That a spacious body is where the energies flow fullest, a terrain ignored at the expense of wholeness.

I liked living more explicitly in sound, then projecting it onto paper. It created a far more interesting interior texture for me than moving always from form to form, as is the case when we type copy, re-presenting the text we have seen elsewhere, on paper or in our own minds. The other graduate students lived constantly with print, the reading it, composing it, inscribing it. I lived at least half with sound. Perhaps it is partly to this that I owe certain unusual events.

Westerners understand letters to be form. The shape of an A heralds the printed alphabet, not the alphabet song of childhood. Sight trumps sound; we read, we do not listen. But the Lamas felt that letters themselves are sounds, which the inscribed shapes merely represent. Their sounds all emerge from, and dissolve back into, the expansive sound of Ah. Intoning this invites inner spaciousness merely by opening the breath and throat for a long, deep Ah. I typed and breathed.

As my facility grew, I became more and more able to produce letters the moment their corresponding sounds, English or Tibetan, came forth on tape. I could type on desktops and keep up with the lecturer. Even better, when it came to transcribing the Lama's speech into letters I no longer paused for tape rewind, spent less time stamping the foot pedal. The möbius was moving again.

An even bigger change occurred when I became an oral translator, directly processing spoken Tibetan sounds into spoken English ones. The former issued from the Lama's mouth, moved through my mind and body, and emerged out my mouth as speech. This speech then entered the ears of other English speakers and from there made its way through their minds, bodies, and beings. As a typist I was a reifier of speech; as an oral translator I moved from one species of sound and life energies to another. The constrictions of form applied less and less.

Translating orally is being in trance. Indeed, as a translator I must be so entranced by Tibetan words that my own words, my random thoughts, are hurriedly suppressed. It is like dreaming someone else's dreams, and dreaming them intensely. When the flow is even and strong, my mind becomes an empty sound board, a kind of aural page, on which the stream of words from the Lama 
are almost simultaneously received and translated. I translate him in other ways as well. Without noticing, I speak forcefully when he throws his voice loud, become softer and slower when he paces down. I even repeat his hand gestures. This is not intentional mimicry, but an unconscious flow of transposition. In facilitating this flow I mimic ancient female roles. Like Yeshey Tsogyal, luminous lady of the wisdom lake and archetypal preserver of Buddhist wisdom words, I too am involved in preservation. Like sibyls of old, I'm a scaled-down oracle; yet it is not the god that descends, but words, though these latter are closely linked in both the East and the West. Most Buddhist words, preserved in print or spoken, come through male voices, though this is changing. The words descend, the sounds and syntax rearrange themselves, move up my lungs with my breath, are shaped by my tongue into English. And, perhaps because I love this process that is also the hardest work I know, perhaps because of the profoundly female charge of ancient archetypes, the wisdom women who saw and heard what others could not remember, something starts being born in me that is thoroughly my own, but I do not see this until much later.

In this way, fulfilling inchoate childhood dreams, I breathe in one language and breathe out another. Afterwards I remember nothing of either. I have to read someone else's notes to find out what's been said. And yet the memory of the sound resides somewhere in my body; days later, when someone touches an elbow, puts a hand on my back, the phrases that have lodged there swirl out and I hear them again.

So it was. I typed, spoke, listened, meditated, read, and wrote between languages, between lives. I moved more and more fluidly between streams of speech, vividly transposing one into the other. Most often these oral translations especially had to do with meditation. Meditation is, among other things, a deep interweaving of those multiple human dimensions that embrace speech, sound, writing, and body in one glorious, sonorous, multitonal hum. Was this a transformative sound? Could typing change my surroundings? The answer, it turns out, is all in the translation.

In Tibetan traditions, meditations are initiated and mediated through the words of the Lama. During centuries of tradition, there have been only a few receptors for the words of any given Lama, whose words could enter only the ears and minds of those actually present in the tent or assembly hall with him. In the hands of a few exceptional students, they might later became notes and still later published as books, words painstakingly carved into wood blocks and the precious pages thus imprinted stored in remote monastic libraries. But now the options have increased. The sound of the Lama's speech can enter telephones, separating his form and sound in ways hardly imaginable even a few decades ago. That same speech can now find its way to tape recorders, videos, and Web sites and be propelled by them far beyond the physical or temporal sight and site of the speaker. 
After years, subjective centuries, of working with translating for Lamas who spoke only Tibetan, I met one who also spoke English. He did not need a translator in the usual sense. But his students, who listened not in classrooms but in rural retreat settings, wanted to see his sound in print. Immediately. So I took the newfangled instrument of this newest need, the flat grey rectangular computer that could sit on my lap, and, instead of tapping my fingers on a wooden desk to keep up with my homeroom teacher, I sat on the floor of a make-shift Tibetan temple streaming with sunshine. I propped the computer on cushions directly in front of the Lama's colorful teaching throne, and brushed actual keys capable of lighting up the letters to represent the sounds of his speech almost as soon as they were spoken.

A different kind of trance resulted. Once again, I focused only on sound, but instead of bringing it through my chest and voice into other sounds, it sped from my ears directly to my fingers and out the keyboard, onto the screen, into the disc. My keen aural attentiveness to his words together with my visual focus on the screen contracts my attention, condensing my thoughts into a state beyond any of the languages of my life. Again and again, the sounds of the Lama collapse into my alert open space, and then emerge on the screen in my lap. Light bounces off the screen, instantly connecting sound, screen, outer and inner space. I am typing faster and faster, binding together in yet another way the sound and the form, and the two minds that produce them, until the two arise simultaneously. They flow into each other, they swirl and change places until the words flowing from my fingers are my own words, describing the space in which all this occurs, and now it is my words that issue and are heard as the voice of the Lama.

My trance-fixed openness to the very words I transmuted has revealed a deeper space wherein I find so much authenticity that it spontaneously repatterns the emergence of speech, exquisitely redesigns the fabric of love and work. What is not said about oracles is this: they do not simply work for others, they voice their own transforming wisdom. It is an important secret.

After this transformation my awareness opens. I return home. I take my newest instrument, an almost-oval dusky blue computer, called an " $i$ book," from my table. I sit on the floor, cushioned by yellow carpeting, place the $i$ book on my lap, and begin to write. The words stream through me, coursing with steadiness from my heart to my hands as the blue writing space softly whirs and stirs, sending its whirs streaming through the open sky light above my head. As I write, I know that a Lama is right now speaking these words that I whir down, while someone somewhere types them into her own space, as I once did, letting it become her story until she is so open to inspiration that she recovers and rewrites a new one. We are all revealers of the texts inside us.

With this revelation I find new sensuality and power in living, languaging, and the love of both. "The path is blocked by vowels and consonants," says the wandering muse. But once muddied waters are flowing again, and the space bar 
is a bar no longer. My mouth and ears no longer closed to foreign tones, knowing no longer busy outside me, I revel in linking revelatory tongues. Words flow again, they stir and whir freely, wholly.

Ask the wrong questions

And the road gets longer

Ask none at all

It will disappear.

Hang with one answer,

You're stuck at a stop sign.

$\mathrm{BHO}^{5}$ the clear eyed beacon seer.

Notes

1. This work itself is no longer extant; like nearly 120 other texts cited by $\mathrm{Li}$-shu sTag-ring, it exists only in the quotations that have come down to us.

2. See Chapter VIII, Verses 90-186 for the classic source for this much-discussed practice. For a popular discussion of it see Pema Chödrön, 1994; for feminist thematizing of issues of self, other, and compassion, see Klein, 1995.

3. Here referring specifically to the Great Completeness or Dzogchen.

4. For reflections on oral/written language in the Tibetan tradition see Klein 1994, and for the intermingling of poetry and the language of logic in Authenticity see Klein 2001.

5. Sanskrit for: Wonderful! Hurrah! Cheers!

\section{References}

Chödrön, Pema. 1994. Start where you are. Boston and London: Shambala.

Cixous, Helene. 1980. "Utopias" in New French feminisms, ed. Elaine Marks and Isabelle de Courivron. New York: Schoken Books

Derrida, Jacques. 1978. Writing and difference. Trans. Alan Bass. Chicago: University of Chicago Press.

Jabès, Edmond.1959. Je bâtis ma demure: Poèmes. Paris: Gallimard.

Johnson, Barbara. 1991. A world of difference. Baltimore and London: Johns Hopkins Press.

Klein, Anne. 1994. Path to the middle, oral Maadhyamika philosophy in Tibet: The spoken scholarship of Kensur Yeshey Tupden. Albany: SUNY, 1-28.

1995. Meeting the Great Bliss Queen: Buddhists, feminists, and the art of the self. Boston: Beacon Press.

2001. Bon Dzogchen on authenticity: Prose, poetry and the path. In Changing minds: Contributions to the study of Buddhism and Tibet in honor of Jeffrey Hopkins. Ithaca: Snow Lion Press. 
Li-shu sTag-ring. 1972 Reprint. gTan tshigs gal mdo rig pa'i tshad ma (The authenticity of open awareness). Delhi: Tenzin Namdak, Tibetan Bon Monastic Centre.

Shantideva. 1996. Bodhisattvac,ry,vat,ra. Trans. Kate Crosby and Andrew Skilton. New York: Oxford.

Anonymous. Anonymous works, otherwise not extant, and for which no other bibliographical material whatsoever is available, are cited in Li shu-sTag-ring, 1972: Man ngag dam pa gsang sde dam pa. (The excellent collection of essential precepts). And Man ngag snying po (Heart of essential precepts). 